\title{
E-Commerce: A Boon for Human Being in Recent
} Era

\author{
Monalisa Hati \\ Assistant Professor, Department of Computer Application, XITE, Jamshedpur, Jharkhand, India
}

\begin{abstract}
Now a days classic shop-based retail is still preferred but E-Commerce, the buying and selling of products and services exclusively through electronic channel gaining popularity. E-commerce can be used for non-digital products especially which have a high value. They can also be used to reach to remote locations. They have a capability to cross the national boarder. People are in a position to conduct various economical transactions on network with the help of E-commerce. E-commerce provides opportunities to all types of Consumers, society and the organization as Market expansion to national and international level, improves brand image of an organization, has $24 X 7$ customer support, reduces paper work, cost, reduces time, process of business is more faster and efficient, increases productivity of organization( supports "pull" type supply management i.e., business process starts when request comes from customer), provides more options to choose products and quicker delivery, provides option to compare the different products and select the better option, customer can get detailed product information before purchasing and gets so much time to discuss with the others before buying a particular product. Due to E-commerce various facilities are now available in remote areas. It also provides awareness in health, education and social services. Most popular product categories among online shoppers in the region include airline tickets and reservations, baby supplies, cosmetics, clothing, accessories and shoes as well as computer hardware and software. In India, 9 percent of the country's population had made a purchase via mobile phone within the past month, as of the fourth quarter of 2014. Everybody having internet connection, those may live in rural or in urban areas can get their products. They do not need to go to various shops to purchase various products wasting time and money because now a days E-commerce has made everything available at home in one place.
\end{abstract}

Keywords: EDI, EFT, E-Payment, Electronic Market

\section{Introduction}

The fast development of telecommunications technology in the past few decades is changing many aspects of our lives how we search for information, how we travel and not at least how we buy products or services. Although classic shop-based retail is still preferred, e-commerce or electronic commerce, namely the buying and selling of products and services exclusively through electronic channels, is gaining ground. The most well-known form of e-commerce or electronic commerce is online shopping, also known as business to consumer e-commerce (B2C), where private customers can order various products which they then receive by courier or postal mail. Another category of ecommerce focuses on transactions between companies, such as manufacturers and a wholesalers or wholesalers and retailers and is called business to business e-commerce (B2B). The third category of e-commerce involves transactions from consumer to consumer $(\mathrm{C} 2 \mathrm{C})$, as in the example of eBay or other similar websites.

E-Commerce refers to paperless exchange of business information using following ways

- Electronic Data Interchange

- Electronic Mail(e-mails)

- Electronic Bulletin Boards

- Electronic Fund Transfer( ETF)

\section{Literature Review}

E-Commerce categories:

1) Electronic markets

Present a range of offerings available in a market segment so that the purchaser can compare the prices of the offerings and make a purchase decision. Example: Airline Booking system

2) Electronic Data Interchange(EDI)

- It provides a standardised system.

- Coding trade transactions.

- Communicated from one computer to another without the need for printed orders and invoices \& delays \& errors in paper handling.

- It is used by organizations that make a large no.of regular transactions.

Example: EDI is used in the large market chains for transactions with their suppliers.

3) Internet commerce:

- It is used to advertise \& make sales of wide range of goods \& services.

- This application is for business to business \& business to consumer transactions.

Example: The purchase of goods that are then delivered by post or the booking of tickets that can be picked up by the clients when they arrive at the event.

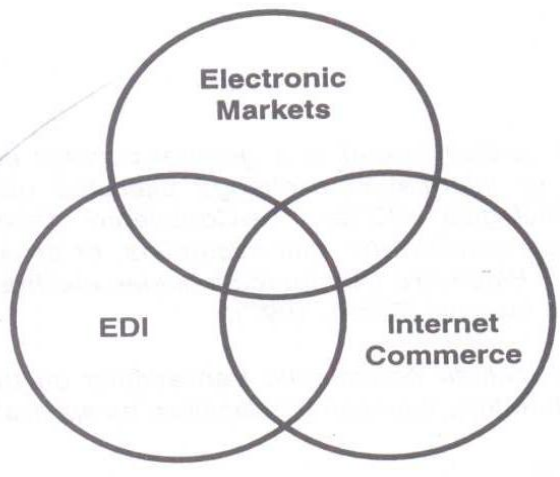

Figure 1: The three categories of E-commerce. Source: www.google.com 


\section{International Journal of Science and Research (IJSR) \\ ISSN (Online): 2319-7064 \\ Index Copernicus Value (2013): 6.14 | Impact Factor (2015): 6.391}

Electronic Commerce and the trade cycle:

a) It can be applied to all, or to different phases of the trade cycle

b) The trade cycle various depending on

- The nature of the organizations

- Frequency of trade between the patterns to the exchange

- The nature of goods and services being exchanged

c) Trade cycle support

1) Finding goods and services (referred to as a search \& negotiation)

2) Placing the order, taking delivery $\&$ making payment (execution and settlement)

3) After sales activities such as warrantee, services etc.

The three generic trade cycles can be identified:

1) Regular, repeat transactions (repeat trade cycle)

2) Irregular transactions, where execution $\&$ settlement are separated (credit transactions)

3) Irregular transactions where execution \& settlement are combined (cash transactions)

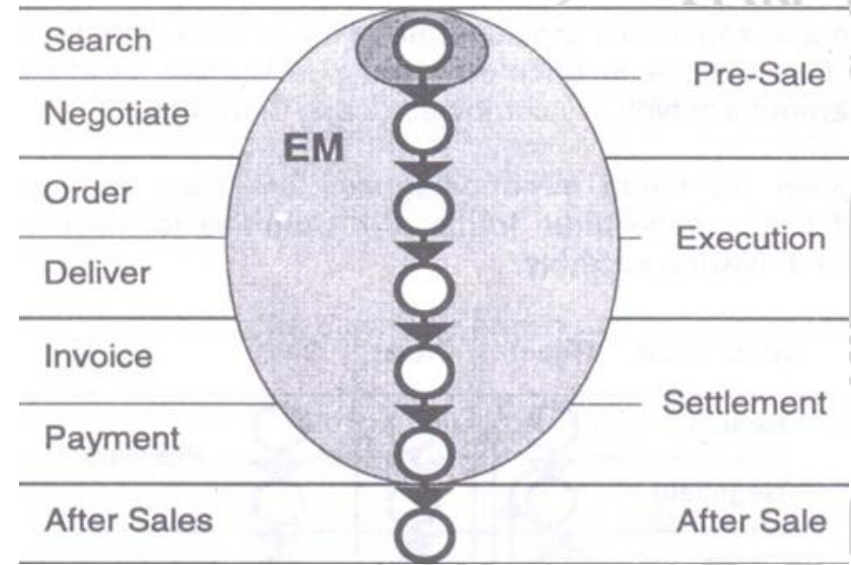

Figure 2: Electronic Commerce and trade cycles

Source:www.google.com

With an expected 33 percent of the global market in 2015 and over 37 percent in 2018, the Asia Pacific region is becoming the leader of the e-commerce industry. In fact, China, due to its unprecedented economic boom, is not only driving the region's leadership, but is also set to outdo the United States as the single country with the largest ecommerce market in the world. Another emerging Asian market in terms of e-commerce is India. Recent statistics show that retail e-commerce sales in India have grown tremendously, from 2.3 billion U.S. dollars in 2012 to an estimated 17.5 billion U.S. dollars, representing an almost eight-fold growth. As of 2015, the retail e-commerce sales as a percent of total retail sales in India are set to account for 0.9 percent of all retail sales in India, but this figure is also expected to grow in the near future reaching $1.4 \%$ in 2018 . By 2016 a number of 653 million people in the Asia Pacific region are expected to buy goods and services online, a figure which translates into over 48 percent of internet users in the Asia Pacific region purchasing products or services online. Some of the most popular product categories among online shoppers in the region include airline tickets and reservations, baby supplies, cosmetics, clothing, accessories and shoes, as well as computer hardware and software.
According to recent data, the number of digital buyers in India alone is expected to reach 41 million by 2016, representing some 27 percent of the total number of internet users in the country. Furthermore, a growing number of people in the Asia Pacific area are increasingly using their mobile devices for online shopping. In India, some 9\% of the country's population had made a purchase via phone within the past months, as the fourth quarter of 2014 .

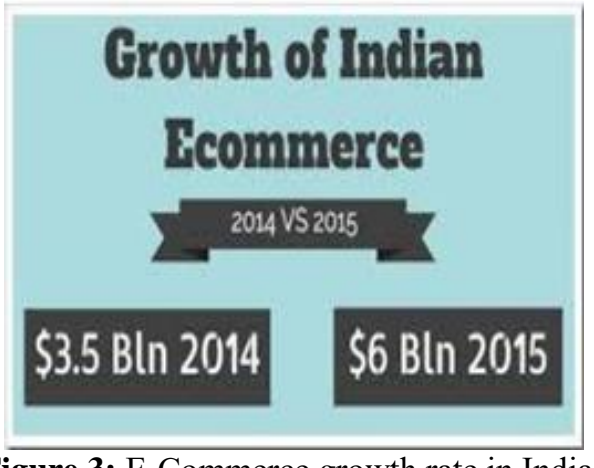

Figure 3: E-Commerce growth rate in India

Source:www.google.com

\section{Analysis}

E-Commerce performs EDI transaction.

- A program generates the file which contains the processed document.

- The document is converted into an agreed standard format.

- The file containing the document is send electronically on network.

- The trading partner receives the file.

- An acknowledgement document is generated and sent to the originating organization.

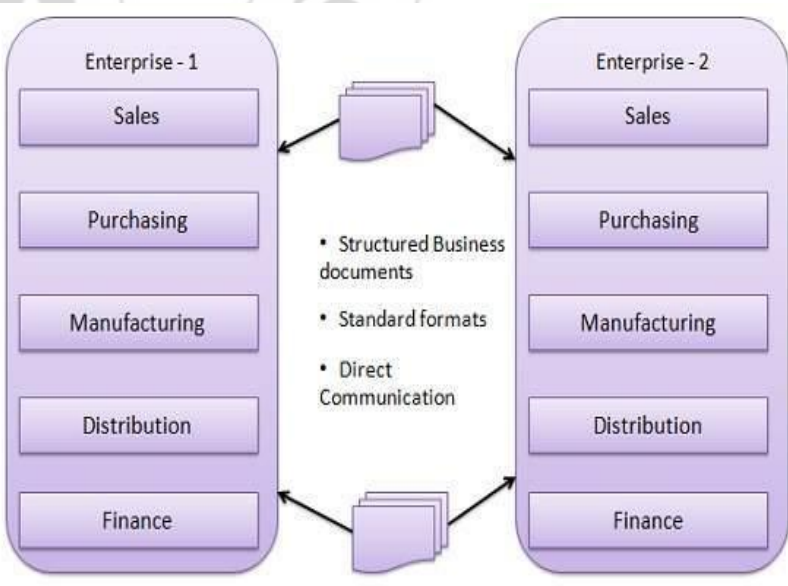

Figure 4: EDI Transaction

Source: www.google.com

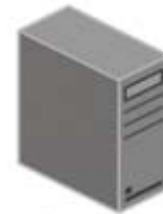

Buyer's

internal system

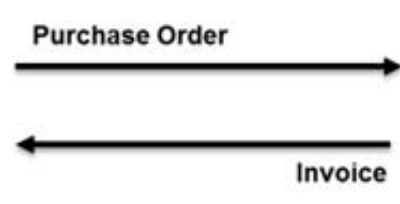

Invoice

Figure 5: EDI document exchange with no people, no paper work involved
Source:www.google.com 


\section{International Journal of Science and Research (IJSR) \\ ISSN (Online): 2319-7064}

Index Copernicus Value (2013): 6.14 | Impact Factor (2015): 6.391

E-Commerce sites use electronic payment which has revolutionized the business processing by reducing paper work, transaction costs, labour cost. Various payment methods:

a) Token-based payment system

- Electronic cash( e.g., Digital Cash)

- Electronic check( e.g., Net Cheque)

- Smart cards or Debit cards

b) Credit card based payment system

- Encrypted credit card( e.g., world wide web form-based encryption)

- Third- party authorization numbers( e.g., First virtual)

c) Electronic fund transfer

Some of the modes of electronic payments are following.

- Credit Card

- Debit Card

- Smart Card

- E-Money

- Electronic Fund Transfer (EFT)

E-payment system provides

d) Integrity \& Authorization

- Out-band authorization

- Password authorization

- Signature authorization

e) Confidentiality

f) Availability \& reliability

E-Commerce has various advantages to organization, consumers and the society.

Advantages to Organization

- Using e-commerce organization can expand their market to national and international markets with minimum capital investment. An organization can easily locate more customers, best suppliers, suitable business partner across the world.

- E-commerce helps organization to reduce the cost to create processes, distribute, retrieve and manages the paper based information by digitizing the information.

- E-commerce improves the brand image of the company.

- E-commerce helps organization to provide better customer service.

- E-commerce helps to simplify the business processes and make them faster and efficient.

- E-commerce reduces paper work a lot.

- E-commerce increases the productivity of the organization. It supports "pull" type supply management. In "pull" type supply management a business process starts when a request comes from a customer and it uses just-in-time manufacturing way.

\section{Advantages to Consumers:}

- 24x7 support. Customers can do transactions for the product or enquiry about any product/service provided by company any time from any location.

- E-commerce application provides user more options and quicker delivery of products.

- E-commerce application provides user more options to compare and select the cheaper and better option.
- E-commerce provides option of virtual auction.

- A customer can put review comments about a product and can see what others are buy or see the review comments of other customers before making a final buy.

- Readily available information. A customer can see the relevant detailed information within seconds rather than waiting for days or weeks.

- E-commerce increases competition among the organizations and as a result organizations provide discount to customers.

\section{Advantages to Society:}

- Customers need not to travel to shop a product thus less traffic on road and low air pollution.

- E-commerce helps reducing cost of products so less affluent people can also afford the products.

- E-commerce has enabled access to services and products to rural areas as well which are otherwise not available to them.

- E-commerce helps government to deliver public services like health care, education, social services at reduced cost and in improved way.

\section{Implementation}

To achieve their vision, ECommerce companies will need to understand the intricate landscape of new markets in addition to their own internal capabilities and limitations. The following factors must be considered:

- Market size: Before moving too aggressively into a new market, it is important to consider how sizable the overall opportunity is.

- E-Commerce readiness: It is essential to fully understanding the payment and logistical infrastructure, consumer behaviour, retail opportunity and technological developments

- Scope of growth: It is also important to look at the internet penetration, demographics of the online buying population and understand which phase of development each market is in.

- Barriers to entry: Players should understand the regulatory environment and connect with solution providers, content distribution networks, and digital agencies.

- Competition: There is also a need to do an in-depth assessment of what competitors are doing, their online strategy and the nature of each offering

\section{Recommendation}

Customer experience: As the customers progress from research to purchase to fulfilment stages, their expectations change fast. E-Commerce companies need to understand these change drivers and adapt their proposition accordingly. Easy transitions between ordering on tablets, mobile phones or PCs will have to be facilitated .Besides, convenient multichannel returns and delivery options need to be developed along with the provisions of touch and feel the product before buying. They should also ensure sufficient after sales service and support. Online product reviews and ratings, videos, more advanced sizing and fitting tools should be provided. 


\section{International Journal of Science and Research (IJSR) \\ ISSN (Online): 2319-7064 \\ Index Copernicus Value (2013): 6.14 | Impact Factor (2015): 6.391}

Technological advancements: E Commerce companies constantly have to upgrade their offerings with changing technology. For instance, shopping through mobiles have truly arrived, they need to devise easy to use mobile apps for their websites. They need to ensure that their websites have the required speed to do fast business, especially during sale, deals and discounts. Solutions enabling seamless integration of back-end and front-end infrastructure, customer experience enhancement initiatives, integrated inventory management and analytics would be crucial for the Ecommerce firms.

Convergence of online and off line channels: As the customers progress from research to purchase to fulfilment stages ,their expectations change fast. Ecommerce companies need to understand these change drivers and adapt their proposition accordingly. Easy transitions between ordering on tablets, mobile phones or PCs will have to be facilitated. Besides, convenient multichannel returns and delivery options need to be developed along with the provisions of touch and feel the product before buying. They should

also ensuresufficientaftersalesserviceandsupport.Onlineproductre viewsand ratings, videos, more advanced sizing and fitting tools should be provided.

Delivery experience With lack of integrated end to end logistics platform, the E Commerce industry is facing issues related to procurement operations and transportation. Online purchasesfromTier-2andTier-3citiesareexpectedto

significantly increase, thanks to the emergence of low cost Smart phones, however, poor last mile connectivity could act as a deterrent. Keeping control on logistics and on ground fleet management, especially courier companies is essential for growth.

Payments and transactions: India continues to be a cashbased society due to limited banking and credit card penetration. This, combined with a lack of consumer trust in online merchants has forced companies to offer COD services, which imposes significant financial cost for firms in the form of labour, cash handling and higher returns of purchased items. Data protection and the integrity of the system that handles the data and transactions are serious concerns. Companies should take necessary action for management even if this imposes a cost on them.

Operational framework: Business models have been evolving rapidly in the E Commerce sector largely due to heightened competition and the inability of players to sustain high costs. Companies in E-Commerce will need to adapt and innovate constantly to sustain their businesses. Several of these companies entered into the E Commerce industry as start ups and have grown to a huge size aided by the continuous growth in the market but lack well defined capabilities and organizational structure. System building, financial and talent management become key.

Customer acquisition: The customer acquisition costs in Indian E Commerce have been climbing rapidly due to intense competition between multiple well-funded players. Only $2 \%$ of website visits currently result into transaction. Thus, there is a gap between potential and actual buyers.
Coupled with high transaction costs, this area could pose serious problems In the US, $75 \%$ of consumers have stated that they will usually switch between brands, and this rate is $60 \%$, according to Ecommerce Foundation. This suggests companies should constantly work on their brand positioning.

Digital infrastructure Digital disruption has driven change in the E Commerce industry with shoppers embracing multiple touch points in their purchase journeys. Companies should spend enough resources on technology development as also advertising and branding, especially because the younger population is demanding. In the journey toward digital business transformation, embedding SMAC technologies in the business becomes crucial.

Addressable markets: To grow their businesses, the Indian Ecommerce sector needs to closely watch the growth of their markets in the Tier 2 and 3 cities. They need to improve their logistics and supply chain management in these cities, do an effective demand management to keep an eye on what products are being sought in these cities. With E Commerce largely being a borderless activity companies need to keep in mind that customers always have the option to buy across the border if they cannot fulfil customers' expectations

\section{Conclusion}

E-Commerce is like a boon for today's human being. Everybody having internet connection, those may live in rural or in town can get their products. They do not need to go to various shops to purchase various products wasting time and money because now a days E-commerce has made everything available at home in one place.

\section{References}

[1] What Indian niche e-commerce companies plan to do in 2015, Medianama http://www.medianama.com/2015/01/223-outlook15niche-e-commerce

[2] The E-Business Revolution, Pentice Hall PTR, 2000

[3] E-Commerce: The Cutting edge of Business, 1999, Tata MC Graw-Hill publishing company limited 